\title{
PENGARUH SEGMENTASI PASAR TERHADAP VOLUME PENJUALAN PRODUK JASA ASURANSI PT. AXA LIFE INDONESIA CABANG LAMPUNG
}

\author{
Yudiana Sari
}

STIE Satu Nusa

\begin{abstract}
The object of this research is PT. Axa Life Indonesia Bandar Lampung Branch. The new slogan used by PT. Axa Life Indonesia "redifining / standards" reflects the desire to be the brand chosen by the public. To understand that people's choices are closely related to their trust in the insurance and financial services industry. The problem under study is wanting to know the effect of market segmentation on the sales volume of PT. Axa Life Indonesia Lampung Branch due to declining sales volume. The research method used in this study is library research and field research conducted by directly examining PT. Axa Life Indonesia Lampung Branch. The results showed that the effect of market segmentation on the sales volume of PT. Axa Life Indonesia Lampung Branch there is a high closeness relationship between the implementation of behavior segmentation with the sales volume of PT. Axa Life Indonesia Bandar Lampung Branch. This is based on the results of calculations through the Kendall Concordation test $(W)$, it is known that there is a high closeness relationship between the implementation of behavior segmentation with the sales volume of PT. Axa Life Indonesia Bandar Lampung Branch. Significant test obtained by calculating X2 value of 162.8 by using critical prices of X2 as a reference, at various levels of alpha can be seen X2 count>X2 table. This means that Ho is rejected and Ha is accepted so it is proven that there is a high closeness relationship between the implementation of behavior segmentation with the sales volume of PT. Axa Life Indonesia Bandar Lampung Branch. In behavior segmentation, it can be seen a qualitative analysis of grouping of buyers based on the expected variables of benefits, price sensitivity, loyalty, and knowledge.
\end{abstract}

Keywords: Segmentation, Sales, Products, Services, Marketing

\section{Pendahuluan}

PT. Axa Life Indonesia Cabang Lampung merupakan salah satu perusahaan yang bergerak dibidang jasa asuransi jiwa baik kesehatan, pendidikan, tabungan serta investasi. Tingginya pertumbuhan diberbagai bidang mampu mendorong munculnya banyak pilihan dalam usaha pemenuhan kebutuhan dari pengkonsumsi. Demikian pula halnya dengan asuransi jiwa yang telah lama berperan serta dalam meningkatkan pertumbuhan perekonomian dunia khususnya Indonesia sesuai dengan usaha kerjanya. 


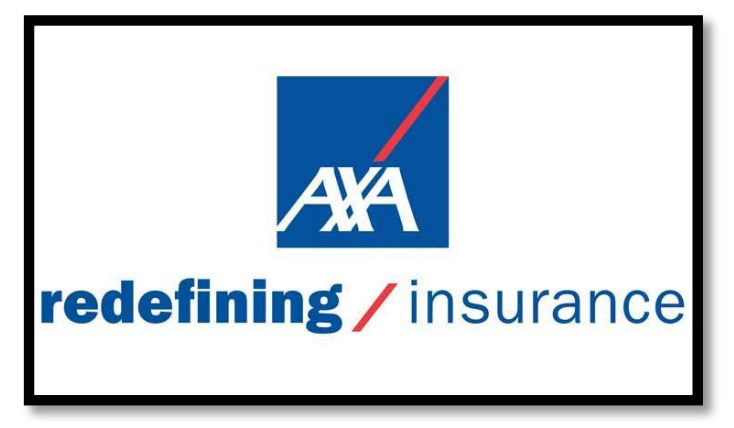

Setiap perusahaan selalu berusaha meraih laba maksimal agar dapat menjamin perkembangan dan kelangsungan hidup perusahaan. Upaya tersebut dapat diwujudkan salah satunya melalui kegiatan pemasaran yang ditunjukkan untuk meningkatkan nilai penjualan melalui pemenuhan pelayanan yang memberikan kepuasan kepada konsumen. Pemasaran adalah suatu proses sosial yang di dalamnya individu dan kelompok mendapatkan apa yang mereka inginkan dengan menciptakan, menawarkan dan secara bebas mempertukarkan produk dan jasa yang bernilai dengan pihak lain. PT. Axa Life Indonesia Cabang Lampung memiliki pasar potensial yaitu seluruh nasabah yang ada di Lampung khususnya Bandar Lampung. Beberapa strategi yang dilakukan adalah dengan mengoptimalkan bauran pemasaran, dimana perusahaan diberikan peluang yang seluas-luasnya untuk memilih dan menentukan bauran pemasaran yang akan digunakan secara otonomi.

Persaingan pangsa pasar untuk produk jasa asuransi unitlink pada PT. Axa Life Indonesia Cabang Lampung dengan Asuransi lain semakin besar. Pada penelitian ini memfokuskan pada segmentasi tingkah laku atas dasar kepekaan harga sebagai tolak ukur untuk mengetahui volume penjualan jasa asuransi pada PT. Axa Life Indonesia Cabang Lampung. Dengan adanya persaingan pangsa pasar kita meneliti apakah ada pengaruh segmentasi tingkah laku dengan volume penjualan PT. Axa Life Indonesia Cabang Lampung.
Tujuan dari penelitian ini adalah untuk mengetahui dan menganalisis bagaimana pengaruh segmentasi tingkah laku konsumen terhadap volume penjualan produk jasa asuransi PT. Axa Life Indonesia Cabang Bandar Lampung

\section{Tinjauan Pustaka}

\section{Pengertian Pemasaran}

Pemasaran dapat dipahami lebih lanjut dengan mendefinisikan konsep pemasaran. Adapun definisi konsep-konsep pemasaran tersebut adalah:

a. Kebutuhan, merupakan tuntutan dasar manusia.

b. Keinginan, merupakan kebutuhan yang diarahkan ke objek tertentu yang mungkin dapat memenuhi kebutuhan tersebut.

c. Permintaan, adalah keinginan akan produk tertentu yang didukung oleh kemampuan untuk membeli.

d. Produk merupakan, segala sesuatu yang dapat ditawarkan kepada pasar untuk diperhatikan, dimiliki, digunakan, atau dikonsumsi sehingga dapat memuaskan keinginan atau kebutuhan. Produk mencakup objek fisik, jasa, orang, tempat organisasi, dan gagasan.

e. Nilai merupakan, perbedaan antara nilai yang dinikmati pelanggan karena memiliki serta menggunakan suatu produk dan biaya untuk memiliki produk tersebut.

f. Kepuasan merupakan, sejauh mana anggapan kinerja produk memenuhi harapan pembeli.

g. Pertukaran adalah tindakan untuk memperoleh objek yang didambakan 
dan seseorang dengan menawarkan sesuatu sebagai penggantinya.

h. Transaksi adalah perdagangan antara dua pihak, yang paling sedikit melibatkan dua macam nilai, persetujuan mengenai kondisi, persetujuan mengenai waktu, dan persetujuan mengenai tempat.

i. Pasar adalah perangkat dari semua pembeli aktual dan potensial suatu produk atau jasa.

\section{Pengertian Manajemen Pemasaran}

Dalam proses melakukan pertukaran barang dan jasa guna memuaskan tujuan individu atau organisasi secara efektif dan efisien perusahaan perlu mengelolanya dengan manajemen pemasaran.

Menurut Philip Kotler (2016: 11) Manajemen pemasaran sebagai seni dan ilmu untuk memilih pasar sasaran serta mendapatkan, mempertahankan, dan menambah jumlah pelanggan melalui penciptaan, penyampaian, dan pengkomunikasian nilai pelanggan yang unggul. Setiap perusahaan perlu mengelola kegiatan pemasaran secara efektif dan efisien.

\section{Konsep Pemasaran}

Konsep pemasaran (Marketing Concept) merupakan orientasi dari manajemen yang beranggapan bahwa tugas pokok perusahaan adalah menentukan kebutuhan, keinginan dan penilaian pasar yang menjadi sasaran dan penyesuaian kegiatan perusahaan sedemikian rupa sehingga dapat memenuhi kepuasan dan keinginan pasar dari pada pesaingpesaingnya.

Konsep pemasaran menurut Basu Swastha DH dan T Hani Handoko (2002:6) didasarkan pada tiga hal pokok yang meliputi :
a. Orientasi kepada konsumen
b. Menyusun kegiatan pemasaran secara integral (Integrated marketing).
c. Kepuasan konsumen (Consumen Satisfaction)

Menurut Basu Swasta DH dan T. Hani Handoko (2002 : 6), konsep pemasaran didefinisikan sebagai berikut :

Konsep pemasaran adalah sebuah falsafah bisnis yang menyatakan bahwa pemuasan kebutuhan konsumen merupakan syarat ekonomi dan sosial bagi kelangsungan hidup perusahaan.

\section{Bauran Pemasaran}

Kebijakan bauran Pemasaran sangat penting dilakukan oleh perusahaan sebagai salah satu usaha untuk suatu persaingan.

Basu Swastha dan Irawan (2000:78) Bauran pemasaran adalah kombinasi dari empat variabel untuk kegiatan yang merupakan inti dari sistem pemasaran perusahaan yakni: Produk, Struktur Harga, Promosi, Saluran Distribusi, Orang-orang, Proses dan Wujud Fisik.

\section{a. Produk}

William J. Stanton (Marius P. Angipora, 2002:152)

Produk adalah sekumpulan atribut nyata (tangible) dan tidak nyata (intangible) didalamnya sudah tercakup warna, harga, kemasan, agen, pabrik, pengecer dan pelayanan.Produk merupakan salah satu elemen utama dalam melakukan kegiatan pemasaran. Philip Kotler (2016;51)

Produk adalah setiap apa saja yang dapat ditawarkan di pasar untuk mendapatkan perhatian, pemakaian atau konsumsi yang dapat memenuhi keinginan atau kebutuhan.

\section{b. Harga}

Jeromy Mc Carthy (Marius P. Angipora, 2002:268) : Harga (Price) adalah apa yang dibebankan untuk sesuatu

Dalam kenyataannya, tingkat harga dipengaruhi oleh beberapa faktor, seperti :

(1) Keadaan perekonomian

Keadaan perekonomian sangat dipengaruhi tingkat harga yang berlaku.

(2) Penawaran dan permintaan

Permintaan adalah sejumlah barang yang dibeli oleh pembeli pada tingkat harga tertentu. Pada umumnya tingkat 
harga yang lebih rendah akan mengakibatkan jumlah yang diminta lebih besar/tinggi. Penawaran merupakan kebalikan dari permintaan, suatu jumlah yang ditawarkan oleh penjual pada suatu tingkat harga tertentu. Pada umumnya tingkat harga yang lebih tinggi mendorong jumlah yang ditawarkan lebih tinggi atau lebih besar.

(3) Persaingan

Harga jual beberapa macam barang sering dipengaruhi oleh keadaan persaingan yang ada. Dalam persaingan ini penjual yang berjumlah banyak aktif menghadapi pembeli yang banyak pula.

c. Saluran distribusi

Dalam usaha menyalurkan atau menyampaikan hasil produksi yang dihasilkan oleh perusahaan, baik berupa barang-barang konsumsi maupun barangbarang industri dari pihak produsen kepada pihak konsumen, saluran distribusi memegang peranan penting. Saluran distribusi merupakan salah satu kebijakan dalam marketing mix yang dapat dikontrol oleh perusahaan. Berikut ini penulis akan mengemukakan pengertian dari saluran distribusi yang akan dikemukakan oleh beberapa ahli dibidang tersebut, agar dapat memberikan gambaran yang jelas tentang pengertian saluran distribusi tersebut.

Kotler (2016:88), mengatakan bahwa :

"Saluran distribusi adalah seperangkat lembaga yang melakukan kegiatan (fungsi) yang digunakan untuk menyalurkan produk dan status kepemilikannya dari produsen ke konsumen"
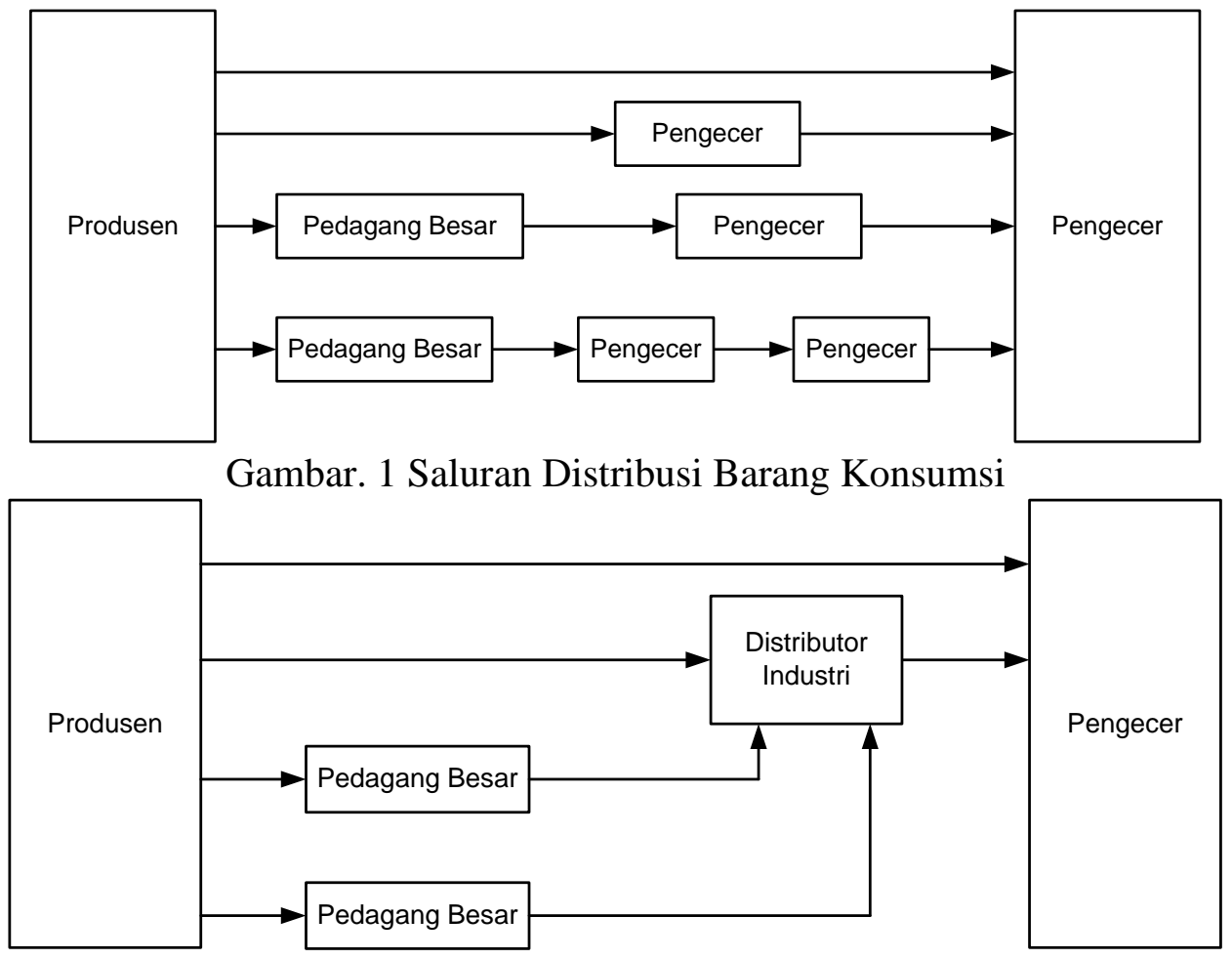

Gambar 1. Saluran Distribusi Barang Industri

Sumber : Philip Kotler, (2016:627)

3. Strategi Pemasaran

Dalam penerapan segmentasi pasar, sebenarnya para marketing memiliki tujuan yang berbeda, namun demikian tetap saja ada satu tujuan utama dalam segmentasi pasar yaitu untuk melayani konsumen secara lebih baik dan memperbaiki posisi kompetitif perusahaan terhadap pesaing. 
Tujuan utama ini juga diiringi dengan tujuan-tujuan lain yang lebih sempit seperti meningkatkan penjualan, pangsa pasar, melakukan komunikasi dan promosi yang lebih baik dan memperkuat citra.

1) Mendefinisikan pasar

Langkah pertama yang harus dilakukan perusahaan adalah mendefinisikan pasar yang akan dihadapi perusahaan. Dalam proses ini perusahaan harus melakukan audit internal terhadap keunggulan dan kelemahan yang dimilikinya. Perusahaan harus mempertimbangkan strategi keseluruhan perusahaan.

2) Mengidentifikasikan dasar-dasar alternatif segmentasi.

Pendekatan segmentasi dapat dibagi menjadi dua, yaitu berdasarkan karakteristik konsumen dan berdasarkan respon konsumen.

3) Memilih dasar terbaik untuk segmentasi.

Suatu perusahaan sebaiknya dapat memperhitungkan cara-cara segmentasi alternatif yang dapat memberikan keuntungan dibandingkan pesaingnya. Salah satu pendekatan untuk menentukan dasar yang tepat untuk segmentasi ini adalah dengan menyusun dasar-dasar segmentasi yang utama dan membaginya lagi kedalam sub-sub yang lebih spesifik.

4) Mengidentifikasi dan menyeleksi segmentasi pasar

Dalam mengevaluasi segmentasi pasar ada tiga faktor yang harus diperhatikan, yaitu: ukuran dan pertumbuhan segmentasi, daya tarik struktural segmentasi, serta sasaran dan sumber daya perusahaan.

a. Target Pasar Sasaran

Setelah mengevaluasi berbagai segmentasi pasar yang ada, perusahaan harus memutuskan segmentasi mana dan beberapa segmentasi yang akan dilayani. Ini merupakan seleksi pasar sasaran. Pasar sasaran terdiri dari kumpulan pembeli dengan kebutuhan atau karakteristik serupa yang akan dilayani perusahaan.

b. Positioning

Setelah memastikan segmen pasar mana yang dimasuki, perusahaan hams memutuskan positioning apa yang hendak ditempatkan dalam segmen tersebut. Positioning mencakup perancangan penawaran, dan citra perusahaan agar target pasar mengetahui dan menganggap penting posisi perusahaan diantara pesaing. Tujuan dilakukannya positioning ini adalah untuk membedakan persepsi perusahaan berikut produk dan jasanya dan pesaing.

c. Konsep Strategi Persaingan Pemasaran Inti dari konsep ini adalah bagaimana perusahaan dapat melakukan strategi yang lebih baik dari pada yang dibuat oleh pesaingnya dalam memuaskan kebutuhan dan keinginan pengonsumsi ditinjau dan posisi persaingan didalam pasar, penentang pasar, pengikut pasar atau penggarap relung pasar.

\section{Pengertian Jasa}

Menurut Philip Kotler (2016: 356) :

Jasa adalah setiap tindakan atau kegiatan yang dapat ditawarkan oleh satu pihak kepihak lain, yang pada dasarnya tidak berwujud dan tidak mengakibatkan kepemilikan apapun. Produksinya dapat dikaitkan atau tidak dikaitkan pada satu produk fisik.

Jasa memiliki empat karakteristik utama yang sangat mempengaruhi rancangan program pemasaran, yaitu:

a. Tidak berwujud (intangibility).

Jasa tidak berwujud. Tidak seperti produk fisik, jasa tidak dapat dilihat, dirasa, diraba, didengar, atau dicium sebelum jasa itu dibeli.

b. Tidak terpisahkan (inseparability).

Umumnya jasa dihasilkan dan dikonsumsi secara bersamaan. Tidak seperti barang fisik yang diproduksi, disimpan dalam persediaan, didistribusikan lewat berbagai penjual, dan kemudian baru dikonsumsi. Jika 
seseorang melakukan jasa, maka penyediaannya adalah bagian dan jasa.

c. Bervariasi (variability).

Karena tergantung pada siapa yang menyediakan serta kapan dan dimana jasa itu dilakukan, jasa sangat bervariasi.

d. Mudah lenyap (perishability).

Jasa tidak bisa disimpan. Mudah lenyapnya jasa tidak menjadi masalah bila permintaan tetap kerena mudah untuk lebih dahulu mengatur setiap waktu melakukan jasa itu.

Strategi pemasaran untuk pemasaran jasa dengan pendekatan 4P sering berhasil untuk barang, tetapi bagi elemen tambahan memerlukan perhatian dalam bisnis jasa. Booms dan Bitner menyarankan tambahan 3P yang terlibat dalam pemasaran jasa: Orang (people), bukti fisik (physical evidence), dan proses (process). Karana sebagian besar yang diberikan oleh orang, seleksi, pelatihan, dan motivasi pegawai dapat membuat perbedaan besar dalam kepuasan pelanggan. Idealnya pegawai harus memperhatikan kompetensi, sikap, memperhatikan responsif, inisiatif, kemampuan memecahkan masalah dan niat baik.

\section{Metodologi Penelitian}

Dua metode penelitian yang digunakan adalah sebagai berikut :

1. Penelitian Kepustakaan

Dilakukan dengan cara membaca dan mempelajari buku-buku, karya ilmiah dan penunjang kepustakaan, yang berhubungan dengan penelitian ini.

2. Penelitian Lapangan
Dilakukan dengan meneliti langsung pada melalui metode wawancara dan penyebaran kuesioner yang berkaitan dengan segmentasi tingkah laku konsumen dan pengaruhnya terhadap volume penjualan PT. Axa Life Indonesia Cabang Bandar Lampung.

Cara menganalisis pengaruh segmentasi tingkah laku konsumen terhadap volume penjualan PT. Axa Life Indonesia Cabang Bandar Lampung dapat dilihat dengan:

1. Analisis Kualitatif

Yaitu menggunakan pendekatan teoritis yang berhubungan dengan manajemen pemasaran dan segmentasi pasar.

2. Analisis Kuantitatif

Alat analisis yang digunakan adalah koefisien korkardansi kendal (W) dengan rumus sebagai berikut:

$$
W=\frac{s}{\frac{1}{12 K^{2}\left(n^{3}-n\right)-K \Sigma}}
$$

Keterangan

$\mathrm{W}=$ Koefisien konkardansi kendal

$\mathrm{S} \quad=$ Jumlah kuadrat deviasi observasi

$\mathrm{K} \quad=$ Banyaknya himpunan ranking perjenjangan

$\mathrm{n} \quad=$ Banyaknya objek/atau individu yang diberi rangking

$\mathrm{T}=$ Faktor koreksi dengan rumus :

$$
T=\frac{\left(t^{3}-t\right)}{12}
$$

$\mathrm{T}=$ Banyaknya Observasi dalam suatu kelompok yang memperoleh angka sama untuk ranking tertentu.

Tabel 1. Tingkat Keeratan Hubungan Koefisien Konkardansi Kendal (W)

\begin{tabular}{|c|c|c|}
\hline No & Besarnya Koefisien & Tingkat Keeratan \\
\hline 1. & $0,00-0,19$ & Rendah sekali \\
\hline 2. & $0,20-0,30$ & Rendah \\
\hline 3. & $0,40-0,59$ & Sedang \\
\hline 4. & $0,60-0,79$ & Tinggi \\
\hline 5. & $0,80-1,00$ & Tinggi sekali \\
\hline
\end{tabular}

Sumber : Sidney Siegel. 
Uji signifikasi dilakukan dengan memasukkan nilai $\mathrm{W}$ dalam rumus ChiKuadrat, sebagai berikut:

$$
\begin{aligned}
& X^{2}=k(n-1) W \text { dengan derajat } \\
& \text { kebebasan }=n-1 .
\end{aligned}
$$

Kriteria pegujian hipotesisnya sebagai berikut:

a. Ho diterima bila X2 observasi $<\mathrm{X} 2$ tabel pada derajat kebebasan dan tingkat kepercayaan tertentu.

b. Ho ditolak bila X2 observasi $\geq X 2$ tabel pada derajat kebebasan dan tingkat kepercayaan tertentu.
Skor yang digunakan untuk setiap jawaban responden adalah:

1) Sangat setuju, skor $=5$

2) Setuju, skor $=4$

3) Ragu-ragu, skor $=3$

4) Tidak setuju, skor $=2$

5) Sangat tidak setuju, skor $=1$

\section{Hasil Pembahasan}

Berdasarkan hasil penelitian dan interprestasi pengaruh segmentasi tingkah laku konsumen terhadap volume penjualan PT. Axa Life Indonesia Cabang Bandar Lampung dapat dilihat melalui tabel 2 sampai tabel 10

Tabel 2. Pelayanan, Konsep Kerja, Dan Perlindungan Hidup di PT. Axa Life Indonesia Cabang Bandar Lampung Lebih Baik Dan Terpercaya Dibanding Asuransi-Asuransi Yang Lain

\begin{tabular}{|l|c|c|}
\hline Alternatif Jawaban & Frekuensi & Persentase (\%) \\
\hline a. Sangat setuju & 7 & 11,67 \\
b. Setuju & 19 & 31,67 \\
a. Ragu-ragu & 22 & 36,66 \\
b. Tidak setuju & 12 & 20 \\
e. Sangat tidak setuju & - & - \\
\hline Jumlah & 60 & 100,00 \\
\hline
\end{tabular}

Sumber : PT. Axa Life Indonesia Cabang Bandar Lampung, 2017

Tabel 3. Dengan Premi > 300.000 Sudah Sesuai Dengan Manfaat Dan Perlindungan Yang Diperoleh

\begin{tabular}{|l|c|c|}
\hline Alternatif Jawaban & Frekuensi & Persentase (\%) \\
\hline a. Sangat setuju & 11 & 18,33 \\
b. Setuju & 38 & 63,34 \\
c. Ragu-ragu & 6 & 10 \\
d. Tidak setuju & 5 & 8,33 \\
e. Sangat tidak setuju & - & - \\
\hline Jumlah & 60 & 100,00 \\
\hline
\end{tabular}

Sumber : PT. Axa Life Indonesia Cabang Bandar Lampung, 2017

Tabel 4. Kepuasan Akan Pelayanan Dan Keramahan Agen-Agen PT. Axa Life Indonesia Cabang Bandar Lampung

\begin{tabular}{|l|c|c|}
\hline Alternatif Jawaban & Frekuensi & Persentase (\%) \\
\hline a. Sangat setuju & 10 & 16,67 \\
b. Setuju & 37 & 61,67 \\
c. Ragu-ragu & 11 & 18,33 \\
d. Tidak setuju & 2 & 3,33 \\
e. Sangat tidak setuju & - & - \\
\hline Jumlah & 60 & 100,00 \\
\hline
\end{tabular}

Sumber : PT. Axa Life Indonesia Cabang Bandar Lampung, 2017

Tabel 5. Menjadi Nasabah PT. Axa Life Indonesia Cabang Bandar Lampung Karena Bermanfaat Dan Terlindungi Hingga Saat Ini 


\begin{tabular}{|l|c|c|}
\hline \multicolumn{1}{|c|}{ Alternatif Jawaban } & Frekuensi & Persentase (\%) \\
\hline a. Sangat setuju & 8 & 13,33 \\
b. Setuju & 31 & 51,67 \\
c. Ragu-ragu & 12 & 20 \\
d. Tidak setuju & 9 & 15 \\
e. Sangat tidak setuju & - & - \\
\hline Jumlah & 60 & 100,00 \\
\hline
\end{tabular}

Sumber : PT. Axa Life Indonesia Cabang Bandar Lampung, 2017

Tabel 6. Anda Memperoleh Banyak Keuntungan Dengan Menjadi Nasabah Produk Asuransi Di PT. Axa Life Indonesia Cabang Bandar Lampung

\begin{tabular}{|l|c|c|}
\hline \multicolumn{1}{|c|}{ Alternatif Jawaban } & Frekuensi & Persentase (\%) \\
\hline a. Sangat setuju & 16 & 26,67 \\
b. Setuju & 27 & 45 \\
c. Ragu-ragu & 10 & 16,67 \\
d. Tidak setuju & 5 & 8,33 \\
e. Sangat tidak setuju & 2 & 3,33 \\
\hline Jumlah & 60 & 100,00 \\
\hline
\end{tabular}

Sumber : PT. Axa Life Indonesia Cabang Bandar Lampung, 2017

Tabel 7. Menjadi Nasabah PT. Axa Life Indonesia Cabang Bandar Lampung Yang Merasa Terlindungi Dan Bermanfaat

\begin{tabular}{|ll|c|c|}
\hline \multicolumn{1}{|c|}{ Alternatif Jawaban } & Frekuensi & Persentase $(\%)$ \\
\hline a. & Sangat setuju & 7 & 11,67 \\
b. Setuju & 31 & 51,66 \\
c. & Ragu-ragu & 15 & 25 \\
d. Tidak setuju & 7 & 11,67 \\
e. & Sangat tidak setuju & - & - \\
\hline Jumlah & 60 & 100,00 \\
\hline
\end{tabular}

Sumber : PT. Axa Life Indonesia Cabang Bandar Lampung, 2017

Tabel 8. Berinvestasi Dan Menyisihkan Uang di PT. Axa Life Indonesia Cabang Bandar Lampung Memperoleh Keuntungan

\begin{tabular}{|c|c|c|}
\hline Alternatif Jawaban & Frekuensi & Persentase (\%) \\
\hline $\begin{array}{ll}\text { a. } & \text { Sangat setuju }\end{array}$ & 3 & 5 \\
\hline b. Setuju & 25 & 41,67 \\
\hline c. Ragu-ragu & 18 & 30 \\
\hline d. Tidak setuju & 13 & 21,66 \\
\hline e. Sangat tidak setuju & 1 & 1,67 \\
\hline Jumlah & 60 & 100,00 \\
\hline
\end{tabular}

Sumber : PT. Axa Life Indonesia Cabang Bandar Lampung, 2017

Tabel 9. Brand image yang baik menjadi faktor anda menjadi nasabah PT. Axa Life Indonesia Cabang Bandar Lampung

\begin{tabular}{|l|c|c|}
\hline Alternatif Jawaban & Frekuensi & Persentase (\%) \\
\hline a. Sangat setuju & 9 & 15 \\
b. Setuju & 31 & 51,66 \\
c. Ragu-ragu & 13 & 21,67 \\
d. Tidak setuju & 6 & 10 \\
e. Sangat tidak setuju & 1 & 1,67 \\
\hline Jumlah & 60 & 100,00 \\
\hline
\end{tabular}

Sumber : PT. Axa Life Indonesia Cabang Bandar Lampung, 2017

Tabel 10. Pentingnya Berasuransi Didapat Setelah Menjadi Nasabah PT. Axa Life Indonesia Cabang Bandar Lampung 


\begin{tabular}{|ll|c|c|}
\hline \multicolumn{1}{|c|}{ Alternatif Jawaban } & Frekuensi & Persentase (\%) \\
\hline a. & Sangat setuju & 5 & 8,33 \\
b. Setuju & 34 & 56,67 \\
c. Ragu-ragu & 12 & 20 \\
d. Tidak setuju & 7 & 11,67 \\
e. $\quad$ Sangat tidak setuju & 2 & 3,33 \\
\hline \multicolumn{2}{|c|}{ Jumlah } & 60 & 100,00 \\
\hline
\end{tabular}

Sumber : PT. Axa Life Indonesia Cabang Bandar Lampung, 2017

Uji koefisien Konkordasi Kendal (W), yaitu:

$$
W=\frac{s}{\frac{1}{12 K^{2}\left(n^{3}-n\right)-K \Sigma}}
$$

Keterangan

$\mathrm{W}=$ Koefisien konkardansi kendal

$\mathrm{S} \quad=$ Jumlah kuadrat deviasi observasi

$\mathrm{K}=$ Banyaknya himpunan ranking perjenjangan

$\mathrm{n} \quad=$ Banyaknya objek/atau individu yang diberi rangking
$\mathrm{T}=$ Faktor koreksi dengan rumus :

$$
T=\frac{\left(t^{3}-t\right)}{12}
$$

$\mathrm{T}=$ Banyaknya Observasi dalam suatu kelompok yang memperoleh angka sama untuk rangking tertentu. Dengan demikian, faktor koreksi dan masing-masing faktor yang berhubungan dengan volume penjualan adalah sebagai berikut:

T Harapan akan manfaat $=$

$$
\begin{aligned}
& \text { Harapan akan manfaat }=\frac{\left(8^{3}-8\right)+\left(6^{3}-6\right)+\left(5^{3}-5\right)+\left(6^{3}-6\right)+\left(8^{3}-8\right)+}{12} \\
& \quad=\frac{\left(8^{3}-8\right)+\left(3^{3}-3\right)+\left(3^{3}-3\right)+\left(3^{3}-3\right)+\left(2^{3}-2\right)+\left(3^{3}-3\right)+\left(3^{3}-3\right)}{12} \\
& \quad=181,5
\end{aligned}
$$

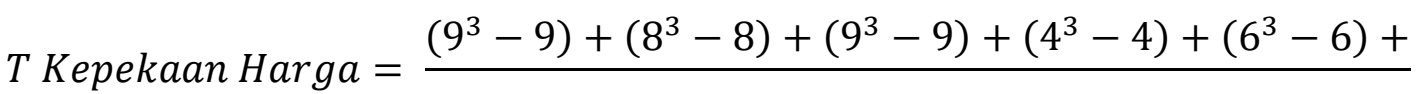

$$
\begin{aligned}
& =\frac{\left(2^{3}-2\right)+\left(2^{3}-2\right)+\left(8^{3}-8\right)+\left(6^{3}-6\right)+\left(2^{3}-2\right)+\left(2^{3}-2\right)}{12} \\
& =246
\end{aligned}
$$

$T$ Loyalitas $=\frac{\left(12^{3}-12\right)+\left(10^{3}-10\right)+\left(3^{3}-3\right)+\left(7^{3}-7\right)+\left(5^{3}-5\right)+}{\left(5^{3}-5\right)+\left(4^{3}-4\right)+\left(3^{3}-3\right)+\left(4^{3}-4\right)+\left(3^{3}-3\right)}$

$$
\begin{aligned}
& =\frac{\left(5^{3}-5\right)+\left(4^{3}-4\right)+\left(3^{3}-3\right)+\left(4^{3}-4\right)+\left(3^{3}-3\right)}{12} \\
& =289,5
\end{aligned}
$$

$T$ Pengetahuan $=\frac{\left(12^{3}-12\right)+\left(8^{3}-8\right)+\left(12^{3}-12\right)+\left(5^{3}-5\right)+\left(9^{3}-9\right)+}{}$

$$
\begin{aligned}
& =\frac{\left(3^{3}-3\right)+\left(3^{2}-3\right)+\left(2^{3}-2\right)+\left(2^{3}-2\right)}{12} \\
& =403
\end{aligned}
$$

Berdasarkan hasil faktor koreksi, maka diperoleh hasil total keseluruhan atribut-atribut segmentasi tingkah laku sebagai berikut:

$$
\begin{aligned}
\sum \mathrm{T} & =181,5+246+289,5+403 \\
& =1.120
\end{aligned}
$$


Nilai W menunjukan derajat hubungan antara segmentasi tingkah laku dalam kaitannya dengan volume penjualan. Beberapa variabel yang terdapat dalam segmentasi tingkah laku, seperti : harapan akan manfaat, kepekaan harga, loyalitas, dan pengetahuan akan dihitung dengan menggunakan Uji Konkordansi Kendall (W) dengan rumus:

$$
W=\frac{s}{\frac{1}{12 K^{2}\left(n^{3}-n\right)-K \Sigma \mathrm{T}}}
$$

Keterangan:

$$
\begin{aligned}
\mathrm{S} & =\sum(\mathrm{Rj}-\mathrm{x})^{2} \\
\mathrm{k} & =196.332,5 \text { (lampiran 5) } \\
\mathrm{n} & =60 \\
\sum \mathrm{T} & =1.120
\end{aligned}
$$

Maka diperoleh :

$$
\begin{aligned}
W & =\frac{196.332,5}{\frac{1}{12}(4)^{4}\left(60^{2}-60\right)-4(1.120)} \\
& =\frac{196.332,5}{287.920-4.480}
\end{aligned}
$$

$$
\begin{aligned}
& =\frac{196 \cdot 332,5}{283 \cdot 440} \\
& W=0,69
\end{aligned}
$$

Dari hasil perhitungan koefisien konkordansi Kendall (W) sebesar 0,69. Untuk menguji hipotesis yang diajukan maka dilakukan uji signifikansi. Uji signifikan dilakukan dengan memasukan nilai $\mathrm{W}$ ke dalam $\mathrm{X}$ kuadrat, yaitu sebagai berikut :

$$
\begin{aligned}
X^{2} & =k(n-1) \mathrm{W} \\
& =4(60-1) 0,69 \\
X^{2} & =162,8
\end{aligned}
$$

Untuk mengetahui apakah hipotesis diterima atau tidak maka dilakukan pengujian dengan menggunakan hargaharga kritis $X^{2}$ sebagai acuan (lampiran 6). Jumlah sampel sebanyak 60 nasabah sehingga d.f $=60-258$. Hasil tersebut tidak terdapat dalam tabel sehingga digunakan derajat bebas yang mendekati jumlah sampel tersebut yaitu (d.f) $=60$. Perbandingan nilai $\mathrm{X}^{2}$ tabel dan $\mathrm{X}^{2}$ hitung dapat dilihat pada tabel 11 dibawah ini

Tabel11.Perbandingan Antara $\mathrm{X}^{2}$ Tabel Dengan $\mathrm{X}^{2}$ Hitung Pada Berbagai Tingkat Alfa

\begin{tabular}{|c|c|c|c|}
\hline \multirow{2}{*}{ Nilai X Hitung } & \multicolumn{2}{|c|}{ Nilai $\mathrm{X}^{2}$ Tabel } & \multirow{2}{*}{ Keputusan } \\
\cline { 2 - 3 } & Alfa & NiIai X & \\
\hline 162,8 & 0,100 & 74,4 & Ho ditolak \\
162,8 & 0,050 & 79,1 & Ho ditolak \\
162,8 & 0,025 & 83,3 & Ho ditolak \\
162,8 & 0,010 & 88,4 & Ho ditolak \\
162,8 & 0,005 & 92,0 & Ho ditolak \\
162,8 & 0,001 & 99,6 & Ho ditolak \\
\hline
\end{tabular}

Sumber : PT. Axa Life Indonesia Cabang Bandar Lampung, 2017

Dengan kriteria pengujian hipotesis sebagai berikut:

1. Ho diterima bila $X^{2}$ hitung $<X^{2}$ tabel pada derajat kebebasan dan tingkat kepercayaan tertentu, berarti hipotesis ditolak.

2. Ho ditolak bila $X^{2}$ hitung $>X^{2}$ tabel pada derajat kebebasan dan tingkat kepercayaan tertentu, berarti hipotesis diterima.
Hasil yang diperoleh yaitu $X^{2}$ hitung lebih besar daripada $X^{2}$ tabel sehingga keputusan yang diambil adalah Ho ditolak, sesuai dengan yang diajukan dalam penelitian ini. Hal ini berarti terdapat hubungan keeratan yang tinggi antara pelaksanaan segmentasi tingkah laku dengan volume penjualan PT. Axa Life Indonesia Cabang Bandar Lampung. 


\section{Kesimpulan}

Berdasarkan pembahasan pada uji koefesien Konkordansi Kendali (W) dapat diambil kesimpulan bahwa terdapat hubungan keeratan yang tinggi antara pelaksanaan segmentasi tingkah laku dengan volume penjualan produk jasa asuransi PT. Axa Life Indonesia Cabang Bandar Lampung. Hal ini didasarkan pada:

1. Hasil perhitungan melalui uji Konkordasi Kendall (W), diketahui terdapat hubungan keeratan yang tinggi antara pelaksanaan segmentasi tingkah laku dengan volume penjualan PT. Axa Life Indonesia Cabang Bandar Lampung.

2. Dalam segmentasi demografi dapat dilihat bahwa 58\% konsumen adalah pria, sebanyak $70 \%$ konsumen adalah profesional sebab $47 \%$. Untuk tingkat pengeluaran perbulan terdapat $63 \%$ diatas Rp.7.000.000,00 dan 37\% dibawah Rp.7.000.000,00. Alat pembayaran yang paling banyak digunakan yaitu secara Auto debet.

3. Dalam segmentasi tingkah laku dapat dilihat analisis kualitatif pengelompokan pembeli yang berdasarkan variabel harapan akan manfaat, kepekaan harga, loyalitas, dan pengetahuan, dapat diambil kesimpulan bahwa:

a. Pengelompokan nasabah berdasarkan harapan akan manfaat sudah baik. Hal ini dapat dilihat dari hasil penelitian yaitu $93,33 \%$ konsumen menyatakan produk asuransi mempunyai basis investasi dan baik bagi nasabah, 88,33\% nasabah berpendapat bahwa konsep kerja produk ini terarah, 55\% menyatakan bahwa PT. Axa Life Indonesia Cabang Bandar Lampung merupakan wadah untuk menyimpan uang untuk masa depan, 48,33\% menyatakan kepercayaan diri mereka menjadi tinggi setelah menjadi nasabah PT. Axa Life Indonesia Cabang Bandar Lampung, 63,34\% menyatakan bahwa menjadi nasabah PT. Axa Life Indonesia Cabang Bandar
Lampung adalah menuju kesuksesan.

b. Pengelompokan nasabah berdasarkan kepekaan harga belum semuanya berjalan baik, ini dilihat masih adanya pengaruh pekerjaan untuk menjadi nasabah. Selain itu dengan menjadi nasabah itu juga menyebabkan pengeluaran menjadi lebih besar dan juga mempengaruhi pendapatan para nasabah.

c. Pengelompokan nasabah berdasarkan loyalitas sudah baik. Hal ini dapat dilihat dari penelitian $81,67 \%$ nasabah premi > Rp.300.000,00 sesuai dengan manfaat yang diperoleh, 78,34\% menyatakan kepuasan akan pelayanan PT. Axa Life Indonesia Cabang Bandar Lampung, 71,67\% menyatakan memperoleh banyak keuntungan menjadi nasabah PT. Axa Life Indonesia Cabang Bandar Lampung, 65\% menyatakan hingga saat ini terlindungi sejak jadi nasabah dan walaupun hanya 43,34\% yang menyatakan konsep kerja PT. Axa Life Indonesia Cabang Bandar Lampung lebih baik dan perusahaan asuransi yang lain. Pengelompokan nasabah berdasarkan pengetahuan sudah cukup baik. Ini dilihat dengan kepercayaan nasabah menginvestasikan uangnya di PT. Axa Life Indonesia Cabang Bandar Lampung dan brand image yang menjadi faktor responden menjadi nasabah PT. Axa Life Indonesia Cabang Bandar Lampung.

\section{DaftarPustaka}

Kotler, Philip, 2016, Manajemen

Pemasaran, Edisi Kelima belas, Alih Bahasa Drs. Benyamin Molan, PT. INDEKS Kelompok Gramedia, Jakarta.

Siegel, Sidney, 2007, Statistik 
Nonparametrik Untuk Ilmu-Ilmu Sosial, Edisi ketujuh, PT. Gramedia, Jakarta.

Stanton, William J, 2003, Prinsip

Pemasaran, Edisi VII Jilid 2, Alih Bahasa oleh Drs. Sadu Sundaru, Penerbit Erlangga, Jakarta.

Swasta D. Basu., 2003, Azas-azas Marketing, Edisi ke II, Penerbit Liberty, Yogyakarta.
Hadi, Sutrisno., 2004, Statistik, Jilid 2, Penerbit Andi, Yogyakarta.

Sugiyono, 2001, Metode Penelitian Administrasi, Edisi VIII, Penerbit CV. Alfabata, Bandung.

Azwar, Saifuddin., 2001, Realibilitas dan Validitas, Edisi III, Penerbit Pustaka Pelajar, Bandung. 